\title{
RESULTS OF SITE INVESTIGATION AND INSTRUMENTATION OF THE KENO GULCH LANDSLIDE/DEBRIS-FLOW SOURCE AREA, ASPEN, COLORADO
}

\author{
By Alan F. Chleborad \\ William L. Ellis \\ Dave Kibler
}

Open-File Report 97-717

This report is preliminary and has not been reviewed for conformity with U.S. Geological Survey editorial standards and nomenclature. Any use of trade, product, or firm names is for descriptive purposes only and does not imply endorsement by the U.S. Government. 


\section{ABSTRACT}

In early May of 1996 the Keno Gulch landslide, located near Aspen, Colorado, spawned destructive debris flows that damaged property and threatened the safety of individuals at the Music Associates of Aspen/Aspen Country Day School campus. The debris flows were triggered by snowmelt during a major warming trend. In early May of 1997 we instrumented the site with a remote-access monitoring system that records and maintains a history of movement, precipitation, and air temperature. An experimental debris-flow detection system was also installed as part of the monitoring effort. The instrumentation revealed movement of the slide mass that was again associated with a major warming trend and rapid snowmelt. The landslide mass did not spawn large debris flows as in 1996. However, smaller debris flows triggered by rainfall and continued snowmelt on ground apparently saturated by prior snowmelt were observed in late May of 1997. Data obtained in the study support the use of a previously identified temperature threshold as a guide to timing future monitoring activities during the Spring snowmelt season.

\section{INTRODUCTION}

The Keno Gulch landslide is located on the west side of Aspen Mountain in the Castle Creek drainage, approximately $1 \mathrm{mi}$ south of Aspen, Colorado (Figures 1 and 2). In early May of 1996, failure of a portion of the landslide resulted in two destructive debris flows. The first occurred on May 13 and the second a day later on May 14; both occurred in late afternoon. The flows mobilized during a period of rapid snowmelt caused by a warming trend that began in early May (Chleborad, 1997). The debris flow descended some $1200 \mathrm{ft}(365 \mathrm{~m})$ to the mouth of Keno Gulch at Castle Creek, where it severely damaged facilities and vehicles at the Music Associates of Aspen/Aspen Country Day School campus.

The landslide is approximately $500-\mathrm{ft}(150-\mathrm{m})$ long and as much as $160-\mathrm{ft}(50-\mathrm{m})$ wide. The depth of the slide is unknown, however, a depth of 10-20 ft (3-6 m) is suggested by the depth of the scar in the slide mass that resulted from the May, 1996 debris flows (Figure 1). Based on the dimensions of the scar the volume of material (rock and soil) lost from the slide is approximately $5,000 \mathrm{yds}^{3}\left(3,800 \mathrm{~m}^{3}\right)$. The volume of the remaining slide material is estimated at 20-30,000 $\mathrm{yds}^{3}\left(15-23,000 \mathrm{~m}^{3}\right)$. An undetermined volume of vegetation (including large aspen and fir trees) covers much of the landslide surface. Large tree parts were incorporated in the debris flows that struck the Music Associates of Aspen/ Aspen Country Day School campus in May of 1996.

Detailed geologic mapping of the landslide site was not undertaken as part of this study. However, geologic mapping of the Aspen Quadrangle by Bryant (1971) indicates the site is in an area underlain by beds of the Belden Formation and Leadville Limestone, both of Paleozoic age, and an aplite porphry intrusive of Cretaceous age. Beds of the Belden Formation and Leadville Limestone in the area dip moderately to steeply to the southeast and are on the faulted west limb of the north plunging Aspen Mountain syncline. Old mine workings, including scattered unconnected tunnels, are numerous in the general area (Bryant, 1972a, 1972b).

Material on much of the surface of the slide area can be characterized as very stony landslide debris and colluvium in a silty to sandy matrix. The stones are angular and generally less than $1 \mathrm{ft}$ in maximum dimension. Some of the material in the upper slide area may have come from mine workings or related activities. Exposed bedrock (aplite porphry (?)) in the area of the headwall (Figure 1) is jointed and highly fractured; these fractures may be significant avenues for ground water migration. A dark shale (Belden Fm. (?) is exposed at seepage locations (Figure 1) in the main scarp in the area of the upper left flank and along the 
Approximate scale

Contour interval $40 \mathrm{ft}$

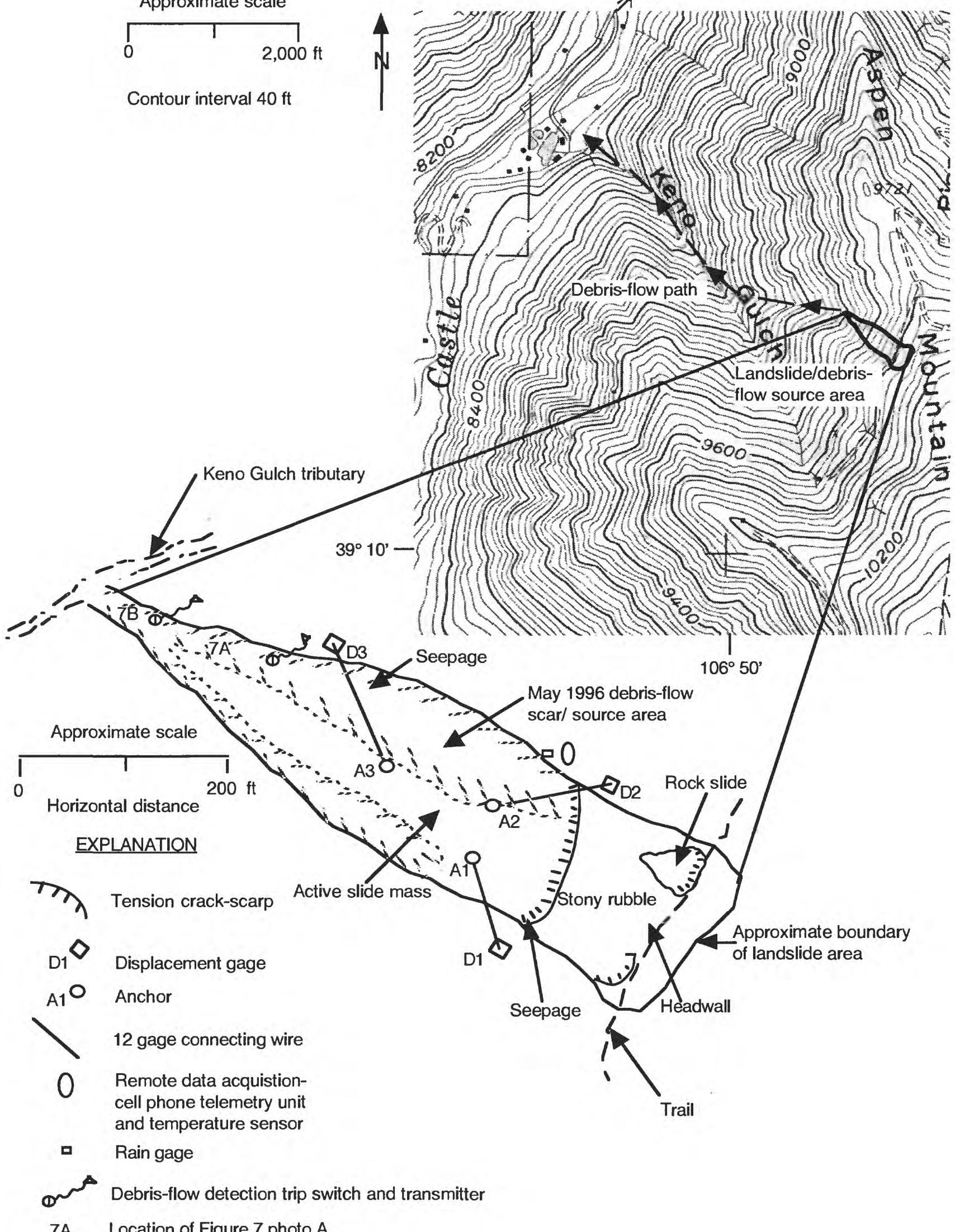

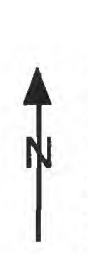

Aspen $1 \mathrm{mi}$.

$7 \mathrm{~A} \quad$ Location of Figure 7 photo $\mathrm{A}$

Figure 1.- - Location map of Keno Gulch landslide/debris-flow source area and sketch map showing location of instrumentation and selected landslide features. 


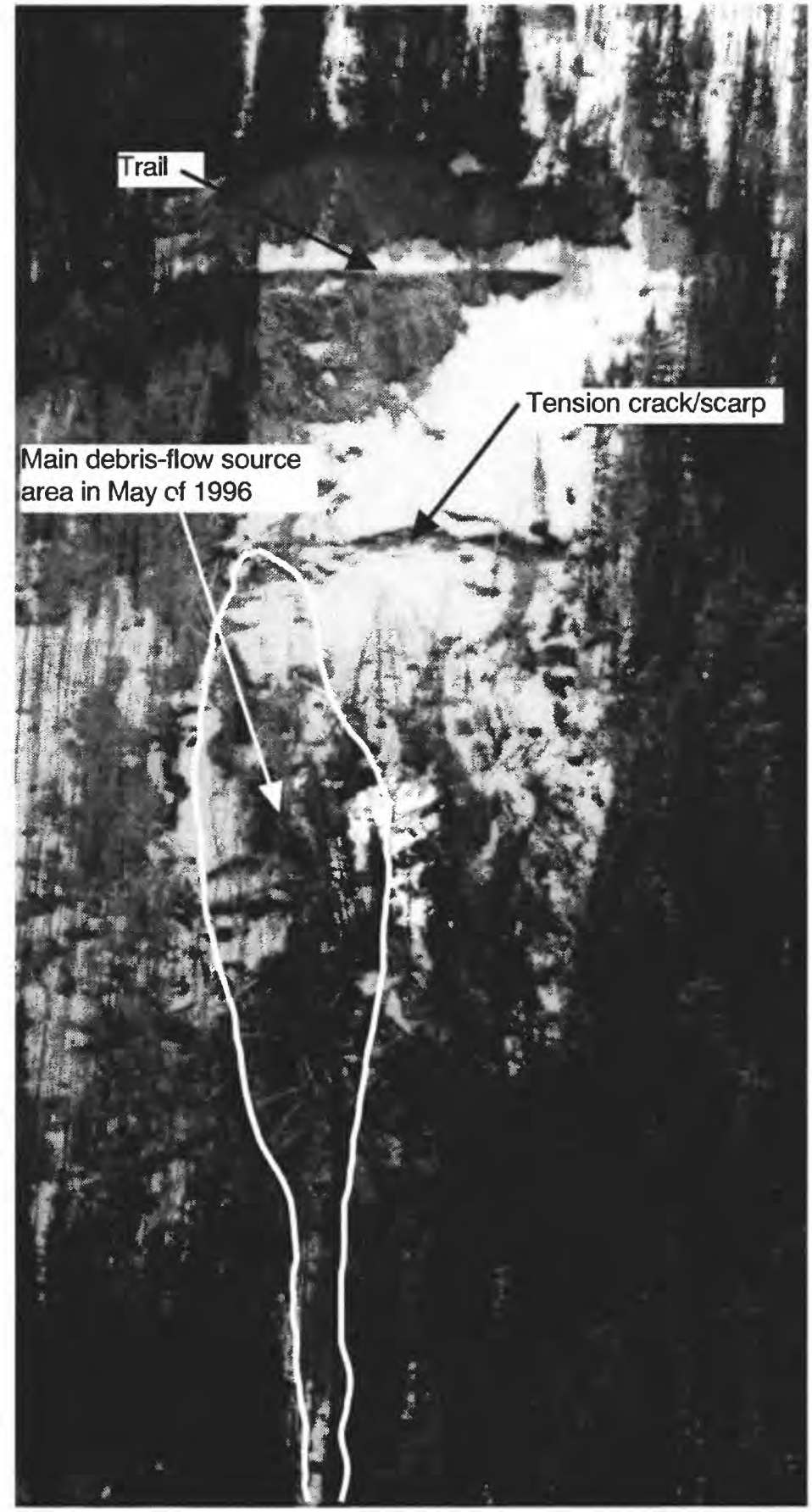

Figure 2.- Aerial oblique photograph of the Keno Gulch landslide/debris-flow source area. Photo was taken May 11th, 1996, two days before the occurrence of the May 13th 1996 debris flow that struck the Music Associates of Aspen/Aspen Country Day School campus. (Photo courtesy of James Blanning). 
lower right flank in the 1996 debris-flow scar/source area. The association of seepage with the shale exposures suggests the shale is relatively impermeable and is acting as a barrier to subsurface water migration, resulting in the concentration of water along the boundary between the shale and more permeable, overlying materials.

The average slope at the site is approximately $34^{\circ}$. However, some slope segments are much steeper. Elevations range from about $9,800 \mathrm{ft}(2,980 \mathrm{~m})$ at the top of the slide area to about $9,400 \mathrm{ft}(2,865 \mathrm{~m})$ at the bottom.

In early May of 1997 we instrumented the site with a remote-access monitoring system that records and maintains a history of landslide movement, precipitation, and air temperature. Additionally, an experimental debris-flow detection system was installed as part of the monitoring effort. Because of the potential hazard of debris flows during and shortly after the critical snowmelt period the Pitkin County Office of Emergency Management was provided periodic updates on landslide movement and climatic conditions recorded at the site.

The purpose of the study was two-fold: (1) to further develop a landslide forecasting capability by acquiring data on time and rate of slide movement, snow depth, air temperature, and precipitation, and (2) to further develop and test the instrumentation and remote-access data recording system. The possibility of debris flows during the Spring snowmelt season is a yearly concern and information that helps forecast the most likely times of occurrence is essential for advance warnings and hazard reduction. This report presents the results of the instrumentation and provides information that may be useful for planning future monitoring activities and reducing the debris flow hazard associated with the Keno Gulch landslide.

\section{ACKNOWLEDGEMENTS}

We thank Robert Baxter, Jons Milnor, Eric Reische, and Matt Reeder of the Aspen Skiing Company for their enthusiastic support during the installation and monitoring phases of the project. The success of the project is due in large part to the cooperation and assistance provided by the Aspen Skiing Company. We also appreciate the cooperation of Steve Crockett, Emergency Management Coordinator for Pitkin County, who utilized information generated in the study to coordinate debris-flow hazard response activities. Sue Cannon of the USGS reviewed the report and provided helpful comments and suggestions.

\section{INSTRUMENTATION}

Field instrumentation included displacement sensors to detect landslide movement, an air-temperature sensor, a rain gage, and an experimental debris-flow detection system. Data were recorded using a data acquisition system equipped with a cellular telephone. The system allowed remote computer dial-in to retrieve stored data. The monitoring system also had the capability of automatically calling out numerically coded alarm reports to up to eight different pager numbers in the event that pre-defined thresholds of deformation or rainfall were exceeded. Displacement and air-temperature readings were recorded once per hour. Rainfall was recorded at 15 minute intervals.

Cable-extension position transducers (CETs), manufactured by Celesco Transducer Products, Inc., were used as displacement gages. Two of the gages (D1 and D3, figure 1) were model PT8420, 4-20mA signal output devices with a measurement range of 0 to $102 \mathrm{~cm}$. $(0-$ 40 in.). Gage D2 was a model PT101 electrical resistance transducer, also with a 0-102 cm (0-40 in. ) measurement range. Because the data acquisition system utilizes a 10 bit A/D converter, the displacement could be monitored with a resolution of approximately $\pm 1 \mathrm{~mm}( \pm$ 0.04 in.). Accuracy of the devices per the manufacturers specifications are $\pm 0.15 \%$ of full 
stroke for the current loop transducers, and $\pm 0.10 \%$ of full stroke for the resistance transducer.

The tipping bucket rain gage used to measure precipitation was model $370 \mathrm{C}$ manufactured by Met One Instruments, which measures rainfall in $0.25 \mathrm{~mm}$ (0.01 in.) increments. Air temperature was monitored using a model AD590 two-terminal integrated circuit transducer manufactured by Analog Devices, Inc. The air temperature could be monitored with a resolution of approximately $\pm 1.0^{\circ} \mathrm{C}$.

The displacement threshold for alarm reporting was maintained at no greater than $0.3 \mathrm{~m}$ (1.0 ft.) above the current displacement readings. Maintaining this threshold provided for relatively early warning in the event of increased displacement rate, a possible precursor to failure of the landslide mass. Rainfall alarm thresholds were set for accumulations of $6.4 \mathrm{~mm}$ (0.25) in 15 minutes, and $12.8 \mathrm{~mm}$ (0.50 in.) in 30 minutes.

Because of the possibility of debris flows during the snowmelt season an experimental debris-flow detection system was incorporated in the monitoring effort. Two weighted 20-liter buckets were placed in the debris-flow channel in the lower part of the landslide area (Figure 1). One was placed adjacent to, and approximately $10 \mathrm{~m}$ downslope from, the main part of the landslide mass and the other about $30 \mathrm{~m}$ below the poorly-defined toe of the landslide. The buckets were positioned on the hillside approximately 3-5 ft $(1-1.5 \mathrm{~m})$ above the channel bottom so runoff or minor debris-flow activity would not impact the buckets and trigger a false alarm. Each bucket was attached by cable to a magnetic-contact switch anchored to a tree at an offslide location. Each magnetic switch was connected in a normally-closed loop configuration to a wireless transmitter. The occurrence of a debris flow sufficient to displace the weighted buckets would therefore result in the separation of the magnetic switches, in turn breaking the normally-closed loops and triggering coded radio transmissions to a receiver located in the data acquisition and telemetry unit. Upon receipt of a coded radio transmission, the monitoring unit would record an alarm condition and initiate an automatic call-out and transmission of a numeric message to the pre-defined pager numbers. The numeric messages would indicate which of the trip alarms had been triggered, and the time of the receipt of each of the radio transmissions. The placement of two trip-alarm installations in the channel provided redundancy and a check in the event one of the alarms might be triggered by non-debris-flow event such as contact by wildlife.

\section{RESULTS OF INSTRUMENTATION}

Installation of instrumentation to record slide movement, rainfall, and air temperature was begun on May 5, 1997 and completed May 6, 1997. The debris-flow detection system was partially installed on May 6 and completed on May 29 as ground conditions improved. All of the instrumentation was removed on July 23, 1997. Data was recorded continuously during the period May 6, 1997 to July 23, 1997 with the exception of a six day period from June 21 to June 27 when a power failure was experienced and no data was collected. Also, recordings from displacement gage installation D1-A1 located at the upper left flank of the slide (Figure 1) were ended on July 6, 1997 when the extension wire between the string gage and the anchor was broken; the cause of the breakage has not been determined.

Displacement gages (fig. 3) were fixed to the trunks of large aspen or fir trees at the offslide locations D1, D2, and D3 shown on Figure 1. Displacement gage anchor points A1, A2, and A3 (Figure 1) consisted of metal plates secured to the trunks of aspen or fir trees growing on the surface of the landslide. The trunks of the anchor trees are approximately $1 \mathrm{ft}$ in diameter at the anchor positions 6-10 $\mathrm{ft}$ above the ground. Deep snow and frozen, rocky ground 


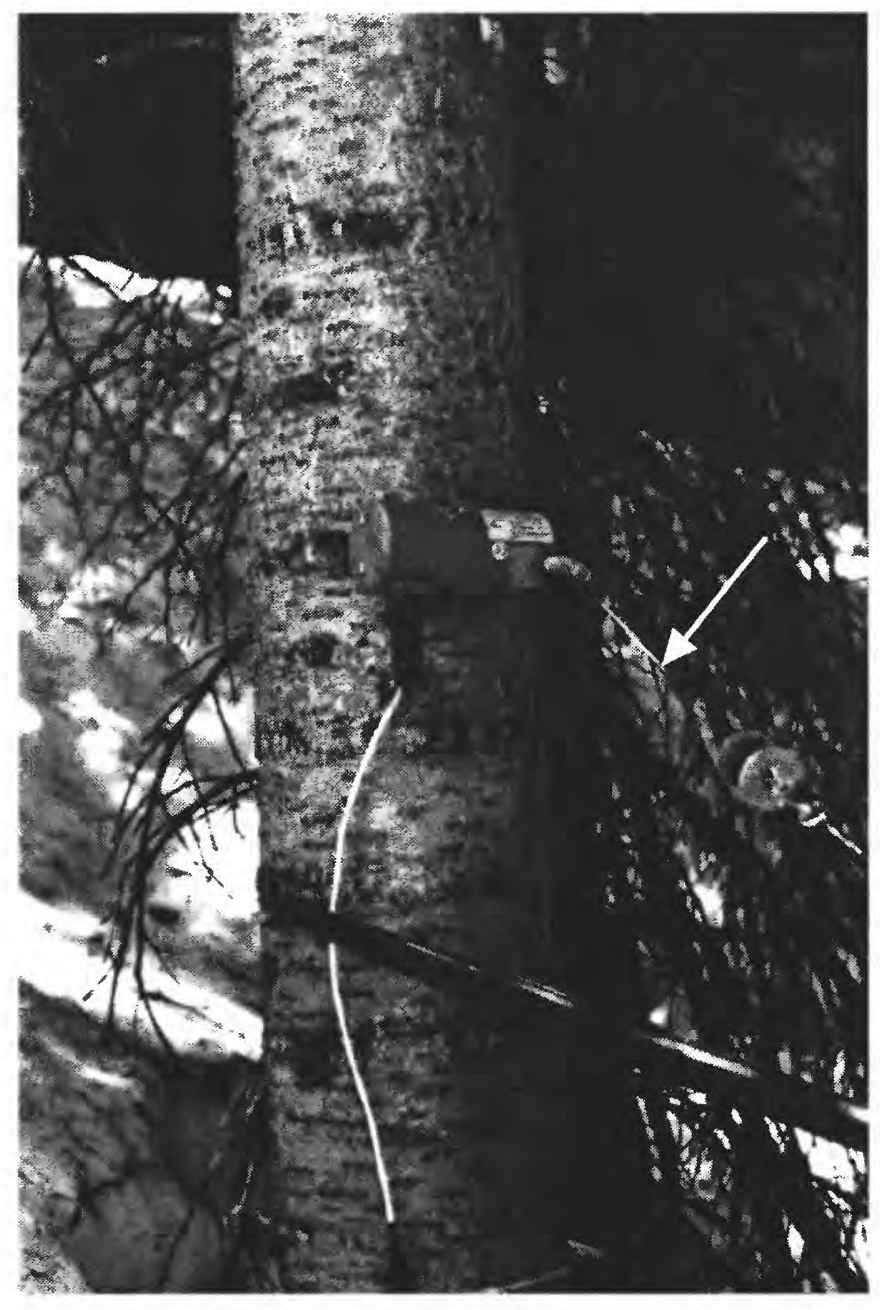

Figure 3.-Photograph of displacement gage D1 located offslide at the upper left flank location shown in Figure 1. Connecting wire to anchor location A1 can be seen extending from the right side of the gage (arrow). White wire below the gage is connected to remote data acquistion unit and power supply on the opposite side of the slide (Figure 1). The displacement gage is approximately $6 \mathrm{ft}(2 \mathrm{~m})$ above ground level and is secured to the $1 \mathrm{ft}$. $(0.3$ $\mathrm{m}$ ) diameter tree with long wood screws. Note that the surface of the snow is approximately $2 \mathrm{ft}(0.6 \mathrm{~m})$ below the displacement gage indicating a snow depth of about $4 \mathrm{ft}(1.2 \mathrm{~m})$ at that location. Photo was taken May 15 , 1997. 
prevented the installation of metal posts as anchor points. Because the anchor trees were subject to unpredictable tilting related to slide movement or other causes, discrimination of displacement caused by tree tilting and actual slide movement was essential. Photographs of the anchor trees and their surroundings were taken at various times from fixed locations to detect changes in orientation due to tilt. Beginning May 15, tree tilt was measured with a Brunton compass. Tilt readings were made to the nearest $1^{\circ}$, parallel and at right angles to the direction of the displacement gage measurements. Approximately $2^{\circ}$ of tilt change was detected at anchor point A3 between May 15 and May 29, 1997. The change in tilt was to the southwest and parallel to the direction of measurement for displacement gage D3. No change in tilt was detected at the other anchor points (A1 and A2). Using standard trigonometric relationships it can be shown that the tree tilt change of $2^{\circ}$ that occurred between May 15 and May 29 at anchor A3 could account for about 3 in. of the total cumulative displacement.

Tape measurements were made between displacement gages and anchor points at the start of the monitoring and during subsequent site visits as a crude check on the cumulative displacements detected by the gages. In all cases, the tape measurements were within $\pm 15 \%$ of the indicated cumulative displacements.

Displacements recorded with the gages have been converted to downslope displacements using the trigonometric relations shown in Figure 4 and plotted as line graphs (Figure 5). In this study, the conversions are based on the assumption that the detected slide movement is in the general downslope direction of the landslide $\left(\mathrm{N} 40^{\circ} \mathrm{W}\right)$ and parallel to well-defined flank boundaries. Because the actual directions of movement may differ from the assumed direction,

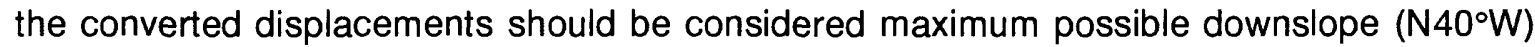
displacements. Similar methods of determining magnitude and direction of slide movement (creep) have been used in other studies (e.g., Savage and Fleming, 1996).

As shown on Figure 5, displacements were detected at all three locations ( $A 1, A 2$, and $A 3$ on fig. 1) at the onset of the monitoring, indicating that slide movement (creep) was already underway when the instruments were installed. Overall, cumulative displacements for the three locations (Figure 5) can be characterized as having four parts based on changes in rate of movement: (1) an initial interval from May 6, 1997 (the starting date) to about May 18, 1997 when rates of displacement were highest and nearly constant, (2) an interval of gradual deceleration between May 18th and May 26, (3) an interval of marked deceleration between May 26 and about June 22nd when the movements slowed to nearly zero, and (4) a final interval of no detectable movement between June 27 and July 23 (the last day of monitoring). Overall, rates of displacement and total cumulative displacements were similar at the three locations. The average rates of movement during the high initial interval (May 6-18) were $1.8,2.2$, and 1.6 in./day at locations $A 1, A 2$, and $A 3$, respectively. Total cumulative displacements during the period May 6th to July 23rd were $4.9 \mathrm{ft}$ at location $\mathrm{A2}, 4.0 \mathrm{ft}$ at location A1, and $3.4 \mathrm{ft}$ at location A3. Short-term displacements that varied from the general trends were recorded at all three locations during the investigation but were especially pronounced at anchor location A3 beginning about May 26 (Figure 5). The cause of the variations is undetermined. Possible causes include temporary disturbance of displacement gage connecting wires by contact with fallen branches, or animals; movement of the anchor tree due to wind, local slide movement, and voltage output fluctuations related to temperature changes.

Plots of cumulative precipitation and temperature are shown on Figure 6. Total cumulative precipitation (rainfall and minor amounts of wet snow) at the site during the monitoring period was 2.53 in. Nearly all of the precipitation occurred during the 10 day 


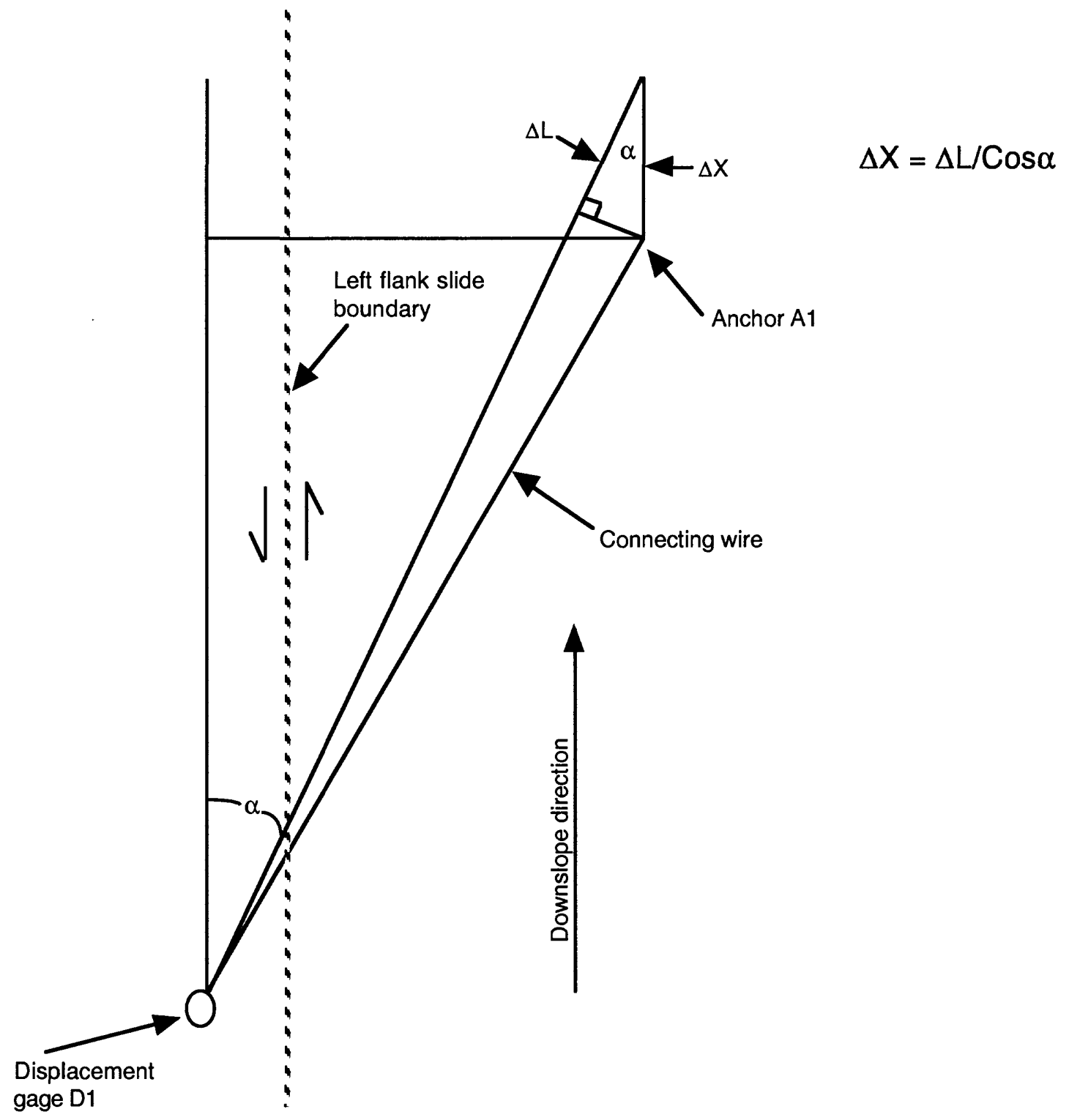

Figure 4.- Sketch of displacement gage installation D1-A1 across left flank slide boundary and trigonometric relations used to calculate downslope displacement parallel to the slide boundary. 


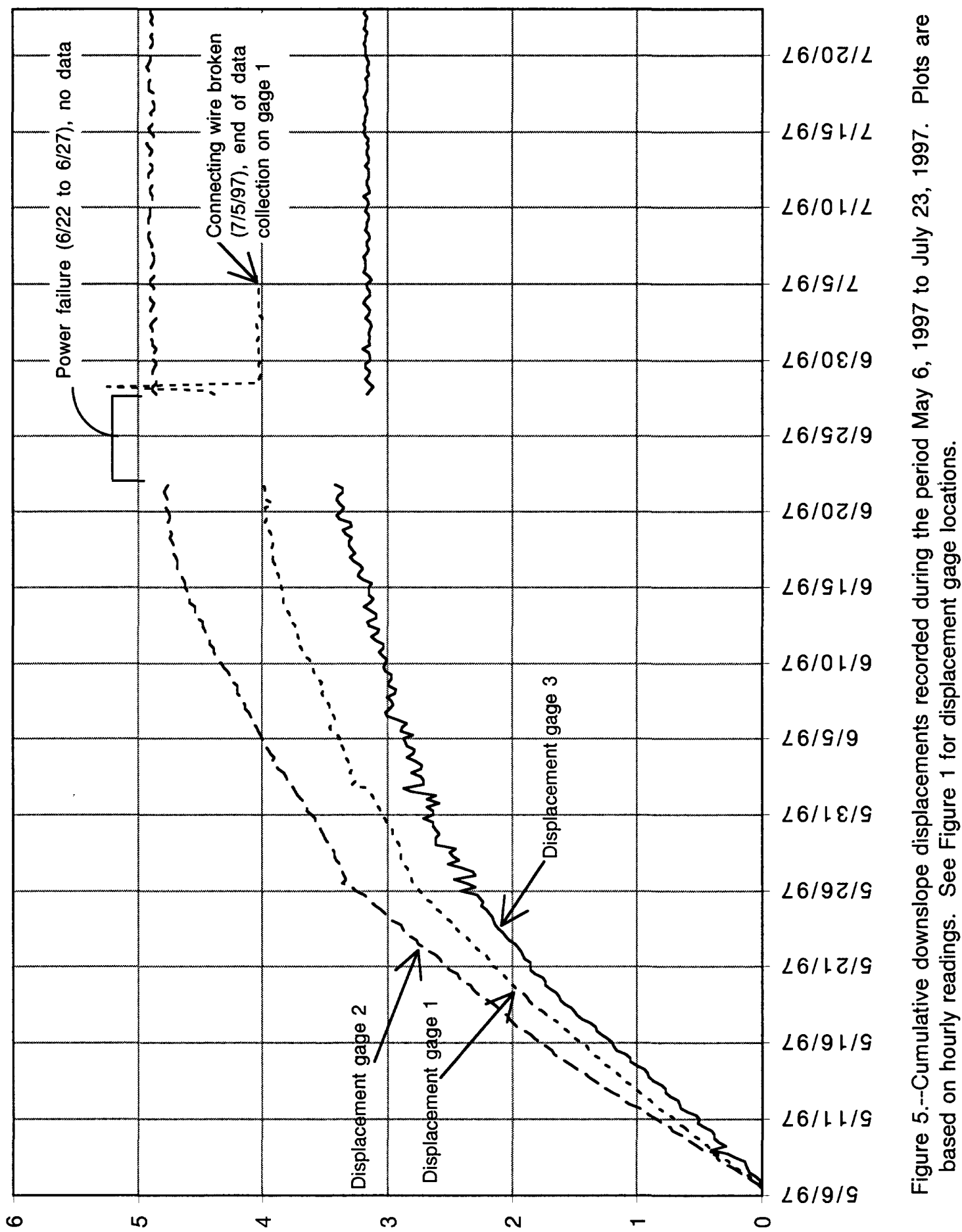

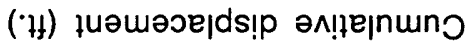




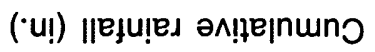

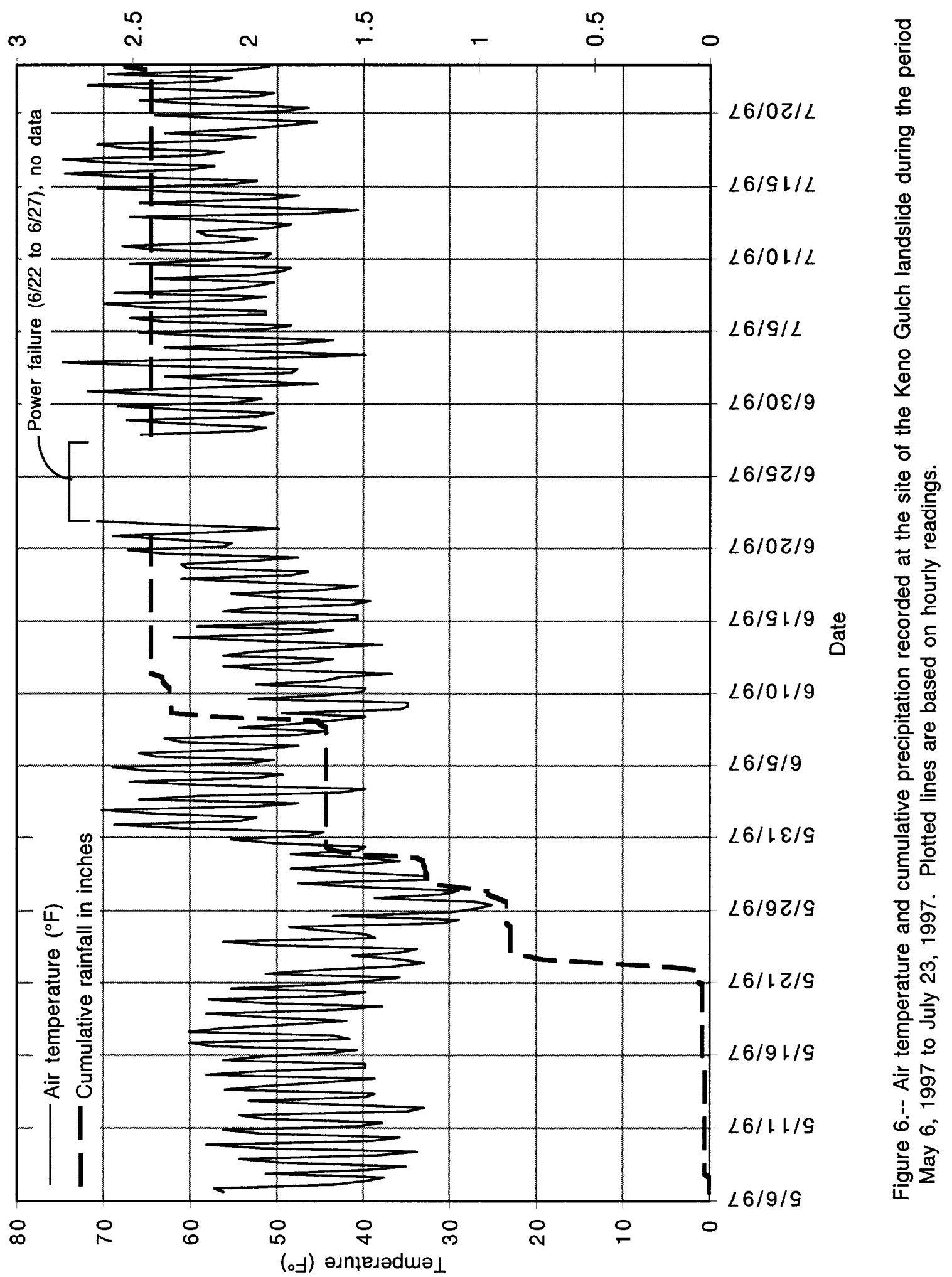


period from May 21 to June 1,1997. Note that the period of gradual deceleration of creep movement of the slide mass between about May 18-26 (Figure 5) roughly coincides with the May 21-29 rainy period that resulted in approximately 1.75 in $(4.4 \mathrm{~cm})$ of cumulative rainfall. During that period rates of precipitation did not exceed $0.25 \mathrm{in} /$ hour and were rarely more than $0.10 \mathrm{in.} / \mathrm{hr}$. As shown on Figure 6, precipitation data was not recorded between June 22 and June 27, 1997 due to a power failure. However, precipitation records from the Aspen 1SW weather observing site located $1 \mathrm{mi}$ northeast of the site indicates no precipitation fell during that time (U.S. Department of Commerce, 1997).

Air temperatures were recorded hourly at the site. During the period May 6-29, the main interval of snowmelt at the slide area, daily maximum temperatures typically occurred in late afternoon and daily minimum in early morning. The highest daily maximum temperature during that period was $60^{\circ} \mathrm{F}$ recorded on May 16 at 5:00 pm and again on May 17 at 12:00 pm. A low temperature of $26^{\circ} \mathrm{F}$ during the May 6-29 period occurred at 6:00 am on May 26. The use of daily air temperature data as a guide for timing future monitoring activities is discussed in greater detail in a following section of this report.

\section{SNOW DEPTH}

Snow depths were measured across the upper part of the slide area during the study to obtain an estimate of average depths and rate of snowmelt. Initial snow depth measurements were made with measuring rods at seven locations across the upper part of the slide area on March 28, 1997. Subsequently, measurements were made on May 7th when the instrumentation was installed and then on May 15 and 29. Additionally, terrestrial photographs were taken of various parts of the slide area on those same dates for the purpose of documentation and comparison of amounts of snow cover. Table 1 shows the ranges and averages of the measured snow depths and estimates of percentage snow cover on the total slide area on the respective dates. Measured snow depths were consistently greater and snow cover longer lasting on the southwest side (left flank) of the landslide than on the northeast side (right flank), apparently due to drifting and differences in exposure to solar radiation related to slope aspect and vegetation canopy. Differences in the average measured snow depths are a crude indicator of the amount of snow loss between successive dates with the exception of the interval between March 28th and May 7th when an undetermined amount of snow was added to the snowpack by storms including a heavy snowstorm in late April.

Table 1. Snow depths across upper slide area and estimates of total snow cover.

\begin{tabular}{||c|c|c|c||}
\hline Date & $\begin{array}{c}\text { Range of measured } \\
\text { snow depths across } \\
\text { upper slide area } \\
\text { (inches) }\end{array}$ & $\begin{array}{c}\text { Average of measured } \\
\text { snow depths across } \\
\text { upper slide area } \\
\text { (inches) }\end{array}$ & $\begin{array}{c}\text { Approximate } \\
\text { snow cover } \\
\text { (\% of total slide } \\
\text { area) }\end{array}$ \\
\hline March 28, 1997 & $49-66$ & 59 & 99 \\
\hline May 7, 1997 & $24-61$ & 46 & 95 \\
\hline May 15, 1997 & $8-44$ & 21 & 70 \\
\hline May 29, 1997 & $0-27$ & 8 & 25 \\
\hline \hline
\end{tabular}




\section{OBSERVATIONS OF DEBRIS-FLOW ACTIVITY}

Very small debris flows (a hundred cubic feet or less in total volume) developed in the lower part of the slide area during the period May 26-29, 1997 (Figure 7). Their initiation was observed by authors Chleborad and Ellis and by Jons Milnor an employee of the Aspen Skiing Company. The debris did not contact the debris flow detection system buckets located higher on the hillside and therefore did not activate the alarm. The flows were apparently triggered by rainfall and continued snowmelt on ground that appeared saturated by prior snowmelt. As indicated in Table 1, the snow cover on the slide area was reduced from approximately $95 \%$ to $25 \%$ between May 7 and May 29. Cumulative precipitation (rainfall) prior to the onset of the debris flows was 0.8 in.; an additional 0.9 in. fell during the period May 26-29 (Figure 6). The flows developed as small amounts of loose, wet surface materials sloughed and slid from the sides of the debris-flow channel and accumulated in the channel bottom. After mixing with water flowing in the channel the debris moved slowly down the drainageway (Figure 7A). Tree parts and large boulders temporarily dammed some of the debris near the bottom of the slide area (Figure 7B). Subsequent breakouts surged down the channel a few hundred feet to the confluence of the debris-flow channel with the small Keno Gulch tributary (Figure 1) that carries spring runoff from the Spar Gulch Diversion. The relatively high volume of water flowing from the tributary diluted the small debris flows such that only pulses of "very muddy water" were observed at the bottom of Keno Gulch.

Although precipitation was not monitored at the site in 1996 prior to the damaging debris flows of May 13 and 14, precipitation data from the Aspen 1SW weather observing site located approximately $1 \mathrm{mi}$ northeast of the site indicates no measurable precipitation fell between May 1 and May 14, 1996. This strongly suggests that snowmelt was the major source of water for the May 1996 slide movement and debris flows. The relative amounts of water contributed by snowmelt on the slide surface and snowmelt from other areas higher on the mountain, prior to the development of the flows, is undetermined. Additionally, water flowing in the Keno Gulch tributary (Figure 1) may have significantly affected the character of the 1996 debris flows as it mixed with debris at the confluence of the debris-flow channel with the tributary.

\section{AIR TEMPERATURE AS A GUIDE TO TIMING FUTURE MONITORING ACTIVITIES}

Shortly after the May 1996 debris flows at Keno Gulch a study of historical snowmelt and snowmelt/rainfall-induced landslides was conducted to examine relationships between antecedent climatic conditions and the times (dates) of occurrence of earliest reported snowmelt season landslide events (Chleborad, 1997). Twenty historical landslide events (mostly debris flows) in the central Rocky Mountain region were profiled, including the May 13, 1996 Keno Gulch debris flow. In the study, a landslide-event date was defined as the date of complete or catastrophic failure as indicated by large amounts of movement or total disruption of the source material. The occurrence of a debris flow is an example of such an event. The study revealed a strong relationship between the occurrence of the landslide events and intervals of rising temperatures that are likely associated with the accelerated production of snow meltwater. Specifically, it was found that a high percentage of the snowmelt related landslide events occurred within 18 days after the first yearly occurrence of a 6-day moving (running) average of daily maximum temperature greater than or equal to $58^{\circ} \mathrm{F}$ at the site.

Based on the results of the study and because indications of an above average snowpack in the Aspen area in early 1997 suggested an increased potential for landslide activity, daily 

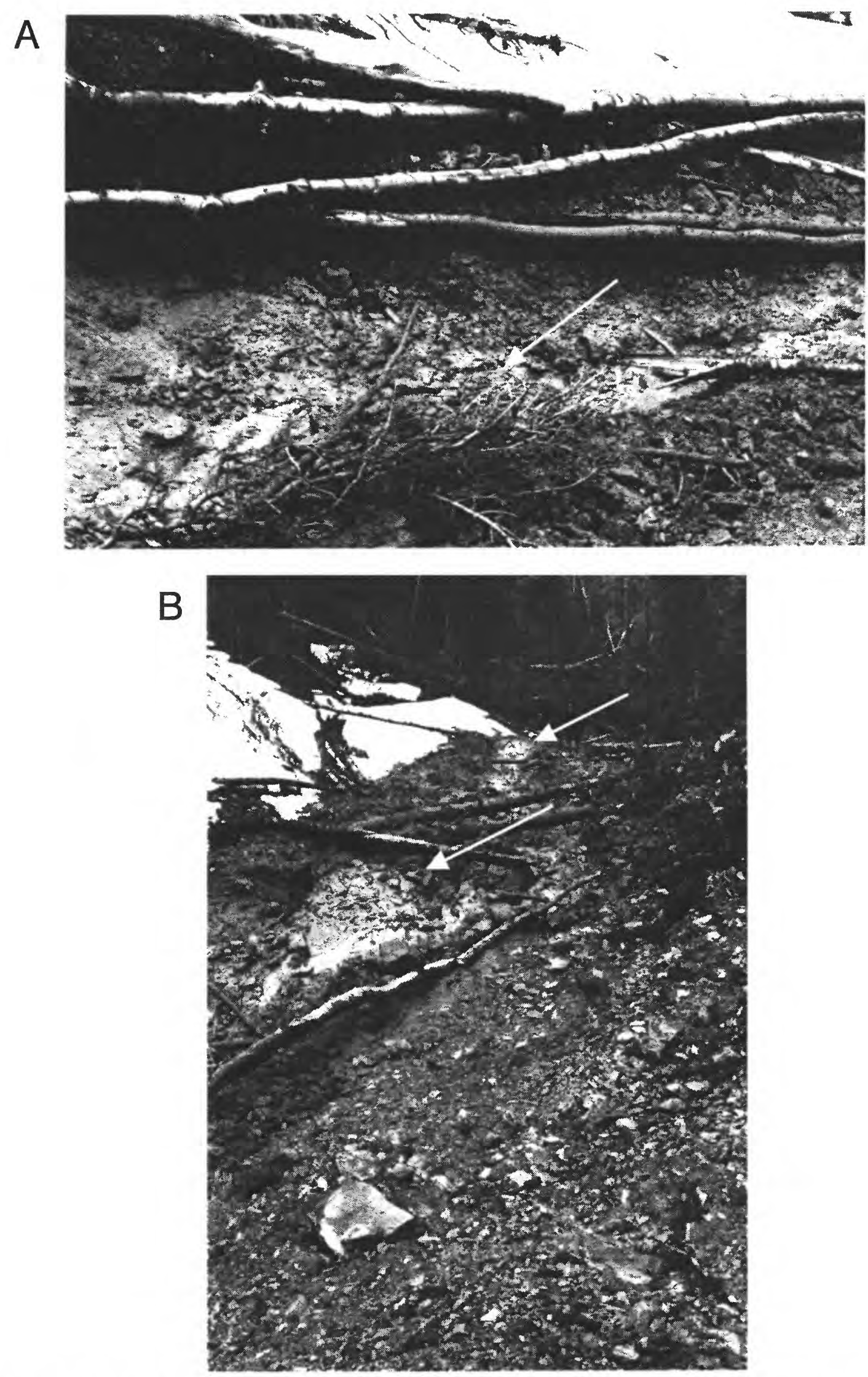

Figure 7.-Photos of May 1997 debris-flow activity in the lower part of the debris-flow scar/source area (see Figure1 for photo locations). Photo A shows snout of small debris-flow (arrow) that was typical of those that occurred during the period May 27-29, 1997. Flow direction is from left to right; view is to the west. Photo B shows debris from small flows dammed by tree parts and large rocks ( arrows). Note remnants of snow cover in upper half of photos. Larger tree parts in photos are approximately 4 to 8 inches in diameter. View is to the northwest. Photos were taken May 29th, 1997. 
maximum air temperatures at Aspen were tracked beginning in early March and 5-day temperature forecasts for Aspen, available on the Internet, were utilized to help predict the likely arrival time of the threshold temperature. As the daily tracking of the 6-day averages progressed it became apparent the first week of May that a significant warming trend was underway that would likely result in the first yearly occurrence of the threshold temperature at the site. Based on that information the decision was made to immediately deploy the instrumentation so that the start of the data recording and observations preceded the arrival of the threshold temperature.

The 6-day moving (running) averages of daily maximum temperature at the Keno Gulch landslide site for March through May of 1996 and 1997 are shown in Figure 8. The 6-day average daily maximum temperature estimates for the site are based on data from the Aspen $1 \mathrm{SW}$ weather substation, located approximately $1 \mathrm{mi}$. northeast of the site, and a lapse rate of $-4.5^{\circ} \mathrm{F} / 1000 \mathrm{ft}$ of elevation. Note that although the 6-day moving averages for 1996 and 1997 closely parallel each other during the warming trends that began in early May of the respective years, the 6-day moving average temperatures were higher by several degrees in 1996, suggesting a higher rate of snowmelt for the same period. As shown in Figure 8, debrisflow activity in 1996 and 1997 was preceded by the first yearly occurrences of the $58^{\circ} \mathrm{F}$ threshold.

Air temperature was measured at the site on an hourly basis between May 6 and July 23, 1997 (Figure 6) using the electrical air temperature sensor described in a previous section. Liquid-in-glass maximum and minimum thermometers in a double top, louvered shelter are most often used at National Weather Service substations (weather observing sites) for daily maximum and minimum temperature observations. The double top is designed to protect the thermometers from precipitation, condensation, and radiation and the louvered construction permits air to circulate freely through the shelter (U.S. Department of Commerce, 1972). Due to time constraints and the need for a remote monitoring capability the readily available electrical temperature sensor was deployed at the site.

Although differences in methods of measurement, type of equipment, and instrument housing used do not allow direct comparison of the measured temperatures with estimated temperatures for the site, both of the methods do indicate that, as in 1996, the onset of debrisflow activity in 1997 occurred after the arrival of the threshold temperature. Based on temperatures recorded at the site, the onset of debris-flow activity in 1997 occurred 8 days after the $58^{\circ} \mathrm{F}$ threshold was reached. Using daily maximum temperature estimates based on Aspen 1SW data, debris-flow activity began 6 days after the arrival of the threshold temperature in 1996 and 16 days after its arrival in 1997. The data and observations of this report appear to support the use of the threshold temperature as a guide to timing future monitoring activities during periods of snowmelt. However, it does not preclude the possibility, however unlikely, of debris-flow activity prior to its arrival and should therefore be used with prudence.

\section{DISCUSSION AND RECOMMENDATIONS}

The results of this study indicate that the slide mass exhibited significant creep movement during the Spring snowmelt season of 1997 . The similarity of displacement histories at the upper and lower slide locations, including average rates and total movement, suggest the recorded displacements were part of a somewhat uniform creep movement of the entire slide mass. None of the three monitored slide locations exhibited accelerated movement 


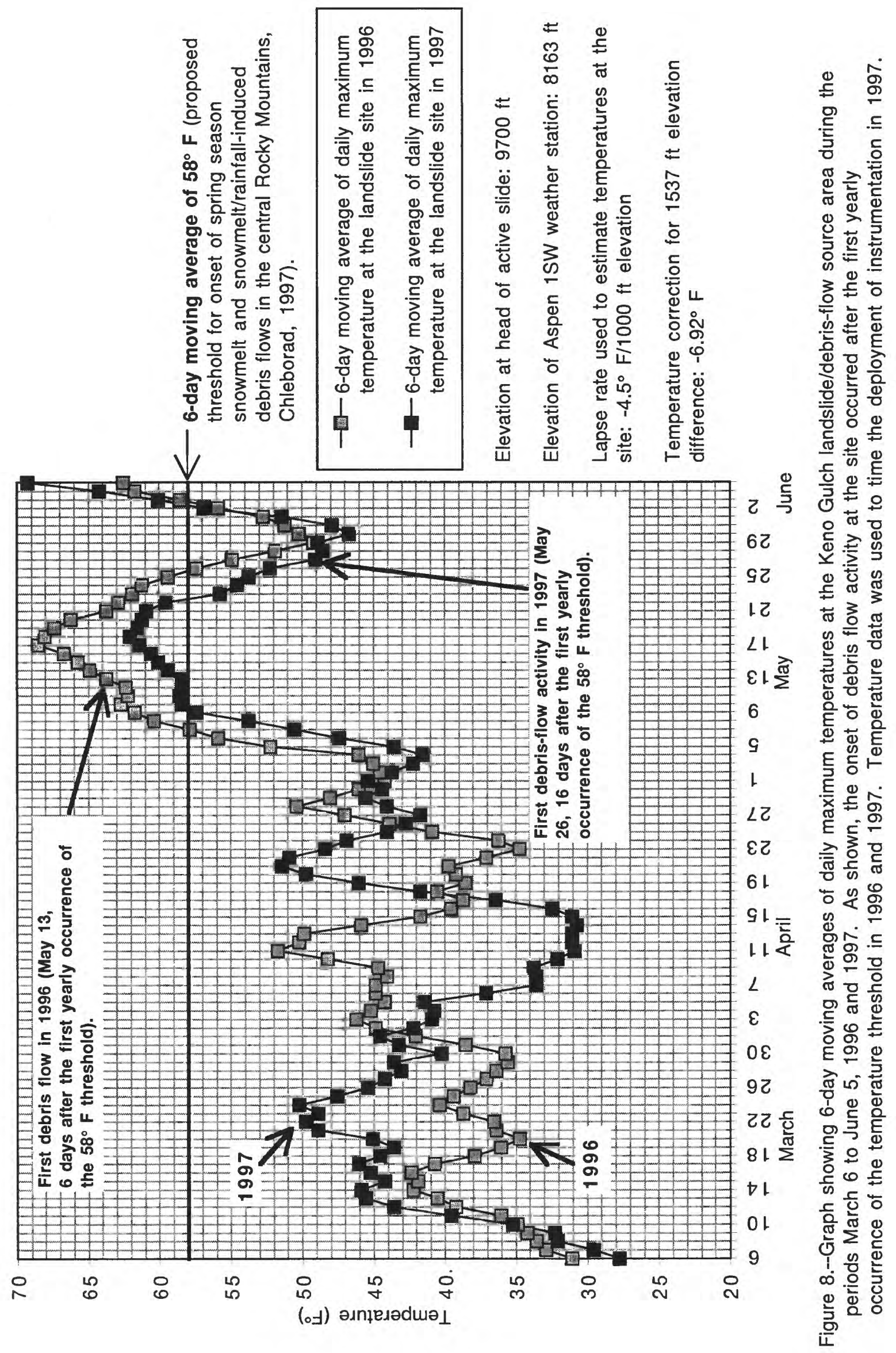


during the investigation. The period with the highest rates of movement (May 6-18, fig. 5), coincides with the major warming trend that occurred during that same time period (Figure 8). It is also significant that no precipitation was recorded during that period (Figure 6). This suggests a direct causal relationship between landslide movement and snowmelt. As indicated on Table 1, there was abundant snow in the area at the beginning of the May 6-18 warming trend. The onset of a marked deceleration of movement occurred at all three measurement locations on about May 26 at the end of a cooling trend that began on May 18 (Figures 5 and 6). Interestingly, the period of gradual deceleration of creep movement of the slide mass between about May 18-26 roughly coincides with the rainy period that resulted in approximately 1.75 in $(4.4 \mathrm{~cm})$ of cumulative rainfall.

Because a large debris flow did not develop during the 1997 monitoring period the reliability of the debris-flow detection system was not tested. A false alarm was received on June 5 when the magnetic switch was activated (decoupled) at the lower installation. Apparently, the false alarm occurred when an animal became entangled with the connecting cable between the bucket and the magnetic switch. Although the false alarm was a nuisance, it did demonstrate that the transmitter and cell-phone components of the system were functioning properly.

Two different scenarios of debris-flow development involving snowmelt are represented by the May 1996 and May 1997 events; (1) debris flows that mobilize during a significant warming trend with rapid snowmelt but little or no precipitation, as in 1996, and (2) debris flows that mobilize immediately or shortly after a significant warming trend during a period of rainfall and continued snowmelt on ground apparently saturated or nearly saturated by prior snowmelt, as in 1997.

The data and observations of this study in conjunction with observations of slide activity in 1996 indicate that the Keno Gulch slide area is prone to landslide movement and debris flows during periods of Spring snowmelt. As a guide to timing future monitoring and site observations during the critical Spring snowmelt season we recommend tracking 6-day moving (running) averages of daily maximum temperatures to determine the arrival time of the previously discussed temperature threshold (Chleborad, 1997). Short term (4-5 day) local temperature forecasts provided by the weather service may be helpful for forecasting the likely arrival time of the threshold temperature. Observations or monitoring to detect landslide movement should begin when the 6-day moving average of daily maximum temperature reaches the low- to midfifties and should be intensified when the $58^{\circ} \mathrm{F}$ threshold is reached. Monitoring of the landslide is also warranted anytime there is intense or long duration rainstorm activity or surface indications that suggest large displacements or accelerated movement.

\section{REFERENCES CITED}

Bryant, Bruce, 1971, Geologic map of the Aspen quadrangle, Pitkin County, Colorado: U.S. Geological Survey Geologic Quadrangle Map GQ-933, scale 1:24,000.

Bryant, Bruce, 1972a, Map showing ground-water potential in the Aspen quadrangle, Pitkin County, Colorado: U.S. Geological Survey Folio of the Aspen Quadrangle, Colorado, Map-I-785-B, scale 1:24,000.

Bryant, Bruce, 1972b, Map showing mines, prospects, and areas of significant silver, lead, and zinc production in the Aspen quadrangle, Pitkin County, Colorado: U.S. Geological Survey Folio of the Aspen Quadrangle, Colorado, Map 1-785-D, scale 1:24,000.

Chleborad, A.F., 1997, Temperature, snowmelt, and the onset of spring season landslides in the Central Rocky Mountains: U.S. Geological Survey Open-File Report 97-27, 35 p.

Savage, W.Z., and Fleming, R.W., 1996, Slumgullion landslide fault creep studies: Chapter 12 in The Slumgullion earth flow: A large-scale natural laboratory: U.S. Geological Survey Bulletin No. 2130, p. 73-76. 
U.S. Department of Commerce, 1972, Air temperature: Chapter 3 in National Weather Service Observing Handbook No. 2, p. 6-15.

U.S. Department of Commerce, 1996, Colorado Climatological Data: Daily temperature data, v. 101, No's 1-5.

U.S. Department of Commerce, 1997, Colorado Climatological Data: Daily temperature data, v. 102, No's 1-5 